\title{
Case fatality ratio of COVID-19 patients requiring invasive mechanical ventilation in Mexico: an analysis of nationwide data
}

Silvio A. Namendys-Silva ${ }^{1,2,3^{*}}$ (D)

As of December 15, 2020, a total of 70,476,836 confirmed cases of coronavirus disease 2019 (COVID-19) had been reported to the World Health Organization, along with 1,599,922 deaths [1]. The demand for hospital and intensive care unit (ICU) beds and resources to care for COVID-19 patients has been significant worldwide. The aim of the present report is to describe the case fatality ratio (CFR) of COVID-19 patients requiring invasive mechanical ventilation in Mexico.

This report analyses of an anonymized patient dataset that is publicly available and accessible to anyone through the Mexican Health Ministry and that was released on December 15, 2020 [2]. All patients with laboratory-confirmed severe acute respiratory syndrome coronavirus 2 infection according to positive reverse transcriptase-polymerase chain reaction approved by adjudication committees or epidemiological associations were included.

The CFR for COVID-19 was calculated as the total number of deaths due to COVID-19 divided by the number of total confirmed COVID-19 cases as of December 15,2020 , multiplied by 100 [3]. A total of 12,018 mechanically ventilated adults with COVID-19 from a previous report were included in the present analysis [4].

Between February 28 and December 15, 2020, a total of 1,267,202 confirmed cases of COVID-19 were reported in Mexico. The sociodemographic characteristics and

\footnotetext{
*Correspondence: antonio.namendyss@incmnsz.mx; snamendys@gmail.com ${ }^{1}$ Division of Pulmonary, Anesthesia and Critical Care Medicine, Instituto Nacional de Ciencias Médicas y Nutrición Salvador Zubirán, 14000 Mexico City, Mexico

Full list of author information is available at the end of the article
}

comorbidities of all patients with COVID-19 in Mexico are shown in Table 1. A total of 115,099 deaths occurred, for an overall CFR of $9.1 \%$. A total of $15.3 \%$ $(39,848 / 260,859)$ of hospitalized patients required invasive mechanical ventilation (IMV), and $70.8 \%$ $(28,209 / 39,848)$ of those patients received IMV outside the ICU (Table 1). Overall, the CRF was higher in patients mechanically ventilated in the ward (outside the ICU) $(23,823[84.5 \%]$ of 28,209$)$ than in those admitted to the ICU (8433 [72.5\%] of $11,639, p<0.001)$. Figure 1 shows the epidemiological curve of the invasively ventilated patients with confirmed cases of COVID-19 (survivor and nonsurvivors) plotted by hospital admission date.

CRF was highest in patients needing intubation and IMV, especially in a setting outside the ICU. The CFR of COVID-19 patients requiring IMV varies greatly between countries; Mexico's CFR for COVID-19 patients requiring IMV is higher than Brazil's $(80.9 \%$ [95\% confidence interval, $80.0-81.8$ ] versus $79.7 \%$ [95\% confidence interval, 78.9-80.5], $p=0.0497$ ) [5]. The COVID-19 pandemic is placing unprecedented demands on Mexico's entire health care system. Over the past 10 months, the number of ICU beds or "beds with ventilators" in Mexico has increased from 2446 to 11,634 [6]. Mexican health authorities have stated that the response to the pandemic has been satisfactory because sufficient number of "beds with ventilators" are available [4]. However, having open "beds with ventilators" in hospital wards does not mean that hospitals are equipped to handle more critically ill COVID-19 patients, which can cause a worsening of the quality of care (CFR can rise). Healthcare systems should be

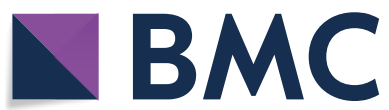

(c) The Author(s) 2021. Open Access This article is licensed under a Creative Commons Attribution 4.0 International License, which permits use, sharing, adaptation, distribution and reproduction in any medium or format, as long as you give appropriate credit to the original author(s) and the source, provide a link to the Creative Commons licence, and indicate if changes were made. The images or other third party material in this article are included in the article's Creative Commons licence, unless indicated otherwise in a credit line to the material. If material is not included in the article's Creative Commons licence and your intended use is not permitted by statutory regulation or exceeds the permitted use, you will need to obtain permission directly from the copyright holder. To view a copy of this licence, visit http://creativecommons.org/licenses/by/4.0/. The Creative Commons Public Domain Dedication waiver (http://creativeco mmons.org/publicdomain/zero/1.0/) applies to the data made available in this article, unless otherwise stated in a credit line to the data. 
Table 1 Patients, deaths, and case fatality ratio for the 1,267,202 confirmed COVID-19 patients in Mexico as of December 15,2020

\begin{tabular}{|c|c|c|c|}
\hline Baseline characteristics & Confirmed cases, N (\%) & Deaths, N (\%) & Case fatality ratio, $\%$ \\
\hline Overall & $1,267,202$ & 115,099 & 9.1 \\
\hline \multicolumn{4}{|l|}{ Age, years } \\
\hline $0-20$ & $69,976(5.5)$ & $519(0.5)$ & 0.74 \\
\hline $21-40$ & $506,113(39.9)$ & $6651(5.7)$ & 1.31 \\
\hline $41-50$ & $262,871(20.7)$ & $13,963(12.1)$ & 5.3 \\
\hline $51-60$ & $210,113(16.6)$ & $25,948(22.5)$ & 12.3 \\
\hline $61-70$ & $126,797(10.0)$ & $32,154(27.9)$ & 25.4 \\
\hline $71-80$ & $64,912(5.1)$ & $24,214(21.0)$ & 37.3 \\
\hline $81-90$ & $23,217(1.8)$ & $10,313(8.9)$ & 44.4 \\
\hline$>90$ & $3203(0.3)$ & $1337(1.16)$ & 41.7 \\
\hline \multicolumn{4}{|l|}{ Sex } \\
\hline Female & $626,096(49.4)$ & $42,011(36.5)$ & 6.7 \\
\hline Male & $641,106(50.6)$ & $73,088(63.5)$ & 11.4 \\
\hline \multicolumn{4}{|l|}{ Comorbidities } \\
\hline Hypertension & $231,328(18.2)$ & $52,593(45.6)$ & 22.7 \\
\hline Obesity & $205,652(16.2)$ & $27,089(23.5)$ & 13.2 \\
\hline Diabetes & $180,165(14.2)$ & $44,367(38.6)$ & 24.6 \\
\hline Cardiovascular disease & $22,343(1.8)$ & $6141(5.3)$ & 27.5 \\
\hline Chronic kidney disease & $21,363(1.7)$ & $8445(7.3)$ & 39.5 \\
\hline Chronic obstructive lung disease & $15,945(1.3)$ & $5460(4.7)$ & 34.2 \\
\hline Immunosuppression & $12,180(0.9)$ & $2792(2.4)$ & 22.9 \\
\hline Medical treatment in the public healthcare system & $1,231,245(97.2)$ & $113,311(98.4)$ & 9.2 \\
\hline Medical treatment in the private healthcare system & $35,957(2.8)$ & $1788(1.6)$ & 5.1 \\
\hline Outpatients & $1,006,343(79.4)$ & $12,111(10.5)$ & 1.2 \\
\hline Inpatients & $260,859(20.6)$ & $102,988(89.5)$ & 39.5 \\
\hline Patients requiring intubation and mechanical ventilation & $39,848(15.3)$ & $32,256(31.2)$ & 80.9 \\
\hline In the intensive care unit & $11,639(29.2)$ & $8433(26.1)$ & 72.5 \\
\hline Outside of the intensive care unit & $28,209(70.8)$ & $23,823(73.9)$ & 84.5 \\
\hline Patients who were not intubated but receiving oxygen therapy & $221,011(84.7)$ & $70,732(68.7)$ & 32.0 \\
\hline
\end{tabular}

concerned about having sufficient qualified personnel and equipment in hospital wards, which has been one of the main problems worldwide during the COVID-19 pandemic. Although the treatment of patients in the ICU has improved in recent years, the standard of care for critically ill COVID-19 patients outside of the ICU is controversial. Daily ward rounds are usually led by an intensivist or critical care nurse (she or he) to explore the critical events for each patient, possible solutions, and prioritization of treatment. This approach can contribute to improved care and decreased CFR in a setting outside of the ICU.

Finally, although this study used nationwide data, administrative data are a source of information regarding real world clinical practices across geographic regions and health systems during the COVID-19 pandemic. 


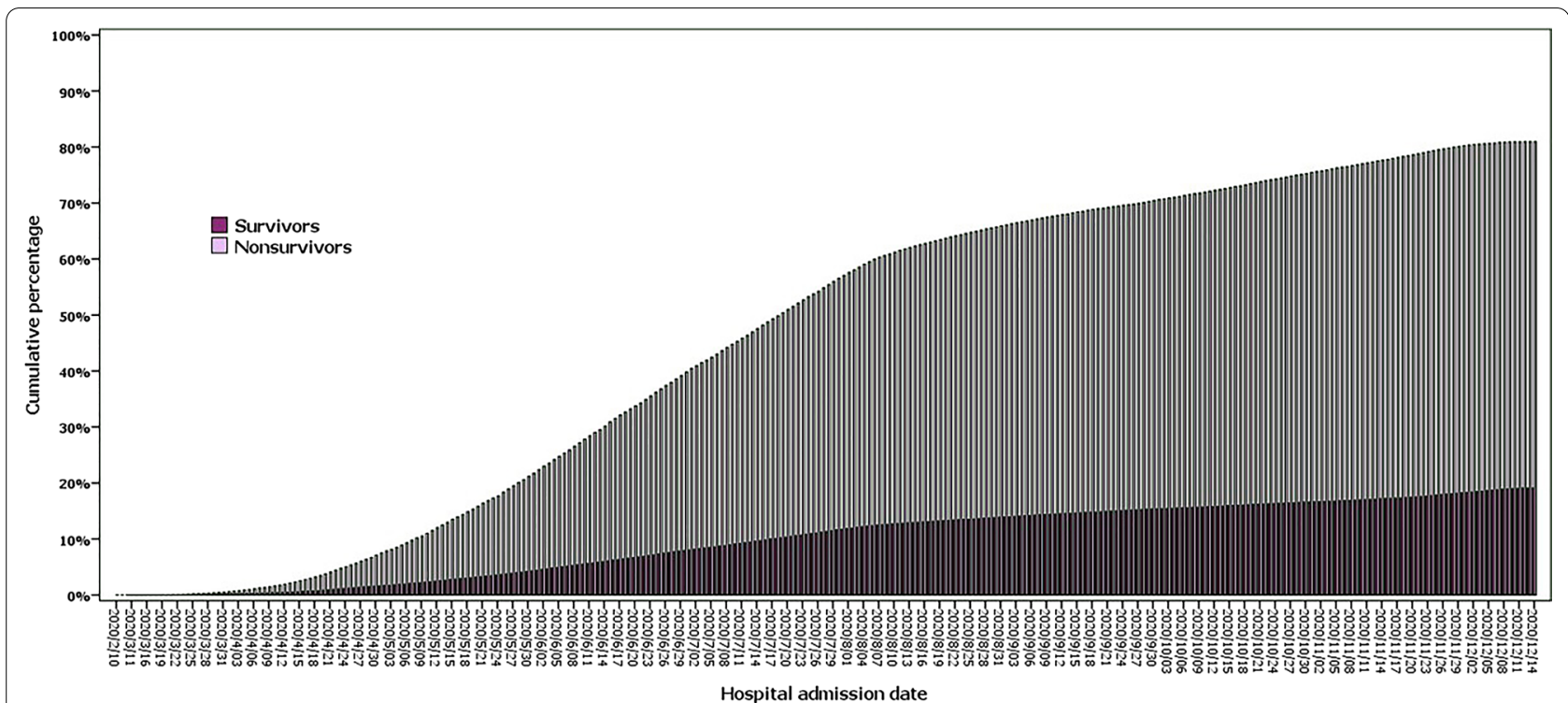

Fig. 1 Epidemiological curve of the invasively ventilated patients with confirmed cases of COVID-19 (survivor and nonsurvivors) plotted by hospital admission date

\section{Acknowledgements}

This report is dedicated to all of the patients and health care workers who died due to COVID-19 in Mexico and around the world.

\section{Author contribution}

The author read and approved the final manuscript

\section{Funding}

No funding to report.

\section{Availability of data and materials}

http://datosabiertos.salud.gob.mx/gobmx/salud/datos_abiertos/historicos /12/datos_abiertos_covid19_15.12.2020.zip (accessed December 16, 2020).

\section{Ethics approval and consent to participate.}

No ethics approval was sought for this study because this study involved the analyses of an anonymized dataset, which is publicly available and accessible to anyone through the Mexican Health Ministry.

\section{Consent for publication}

Not applicable.

\section{Competing interests}

The author states that there are no conflicts of interest related to this report.

\section{Author details}

${ }^{1}$ Division of Pulmonary, Anesthesia and Critical Care Medicine, Instituto Nacional de Ciencias Médicas y Nutrición Salvador Zubirán, 14000 Mexico City, Mexico. ${ }^{2}$ Department of Critical Care Medicine, Instituto Nacional de Cancerología, Mexico City, Mexico. ${ }^{3}$ Society of Physicians of Medica Sur (Member), Mexico City, Mexico.

Received: 28 January 2021 Accepted: 1 February 2021

Published online: 16 February 2021

\section{Reference}

1. World Health Organization. COVID-19 Weekly Epidemiological Update (2020). https://www.who.int/docs/default-source/coronaviruse/situa tion-reports/20201215_weekly_epi_update_18.pdf?sfursn=9c9aa c11_5\&download=true. Accessed January 26, 2021.

2. Datos Abiertos - Dirección General de Epidemiología, Secretaría de Salud, Gobierno de México. http://datosabiertos.salud.gob.mx/gobmx/salud /datos_abiertos/historicos/12/datos_abiertos_covid19_15.12.2020.zip. Accessed December 16, 2020.

3. World Health Organization. Estimating mortality from COVID-19: Scientific brief, 4 August 2020. https://apps.who.int/iris/rest/bitstreams/12899 37/retrieve. Accessed January 26, 2021.

4. Ñamendys-Silva SA, Gutiérrez-Villaseñor A, Romero-González JP. Hospital mortality in mechanically ventilated COVID-19 patients in Mexico. Intensive Care Med. 2020;46(11):2086-8.

5. Ranzani OT, Bastos LSL, Gelli JGM, et al. Characterisation of the first 250000 hospital admissions for COVID-19 in Brazil: a retrospective analysis of nationwide data [published online ahead of print, $2021 \mathrm{Jan}$ 15]. Lancet Respir Med. 2021;S2213-2600(20)30560-9.

6. Secretaría de Salud, Gobierno de México. Versión estenográfica. Conferencia de prensa (25/04/2020). Informe diario sobre coronavirus COVID-19 en México. https://www.gob.mx/presidencia/es/articulos/version-esten ografica-conferencia-de-prensa-informe-diario-sobre-coronavirus-covid -19-en-mexico-241021?idiom=es. Accessed January 26, 2021.

\section{Publisher's Note}

Springer Nature remains neutral with regard to jurisdictional claims in published maps and institutional affiliations. 